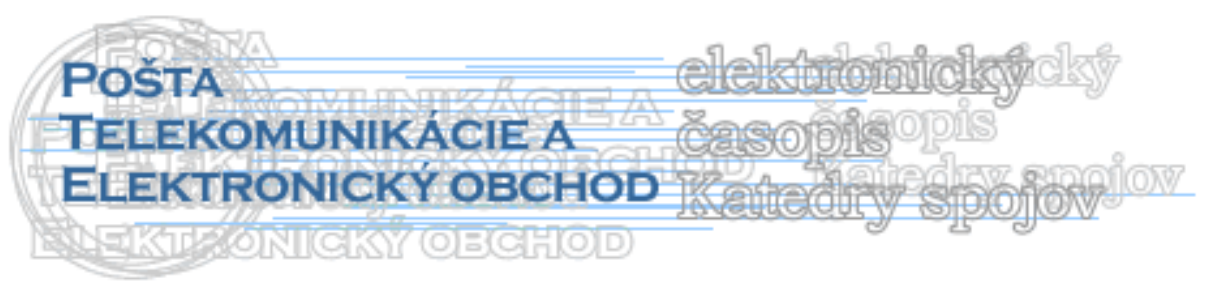

\title{
NÁVRH ELEKTRONICKÉHO SYSTÉMU OZNÁMENIE O ULOŽENÍ ZÁSIELKY PROSTREDNÍCTVOM SMS SPRÁVY - 2. ČASŤ
}

\author{
Tomáš Šimek, Juraj Vaculík ${ }^{1}$
}

\section{Úvod}

Ciel'om návrhu je zlepšenie súčasných služieb poskytovaných Slovenskou poštou implementáciou mobilných elektronických služieb. Navrhujeme možné zlepšenie procesu doručovania zásielok. Konkrétne sa zameriame na proces Oznámenie o uložení zásielky. V nadväznosti na predchádzajúcu čast' $\mathrm{v}$ tejto uvádzame popis fungovania systému a návrh architektúry.

\section{Popis fungovania systému}

Typy používatel'ov systému môžeme rozdelit' do týchto skupín:

- Zákazníci - prijímajú notifikačné správy o uložení zásielok

- Pracovníci pošty - registrácia zákazníkov na pošte, evidovanie uložených zásielok

\subsection{Zákazníci}

Ak sa zákazník rozhodne službu používat' je potrebné:

- Vlastníctvo mobilného telefónu s platnou SIM kartou

- Registrácia telefónneho čísla zákazníka pre konkrétnu poštovú adresu

Je viacero možností ako sa môže zákazník zaregistrovat'. Ako najvhodnejšie sa ukazujú nasledovné:

- Prostredníctvom WWW portálu - vyplnením a odoslaním registračného formulára, napríklad podl'a formátu na Obr. 1

- Registračnou SMS správou - zaslaním špeciálnej SMS správy na vopred zadané telefónne číslo

- V pobočke pošty - vyplnením registračného formulára

Navrhovaný elektronický systém oznámenia o uložení zásielky by mal fungovat' súbežne s klasickým spôsobom z týchto dôvodov:

\footnotetext{
${ }^{1}$ Mgr. Tomáš Šimek, doc. Ing. Juraj Vaculík, PhD. Žilinská univerzita v Žiline, Fakulta prevádzky a ekonomiky dopravy a spojov, Katedra spojov, tomas.simek@gmail.com, juvac@,fpedas.uniza.sk
} 
- nie každý adresát vlastní mobilný telefón,

- nie každý adresát by mal o danú službu záujem,

- nie každý adresát si zaregistruje číslo.

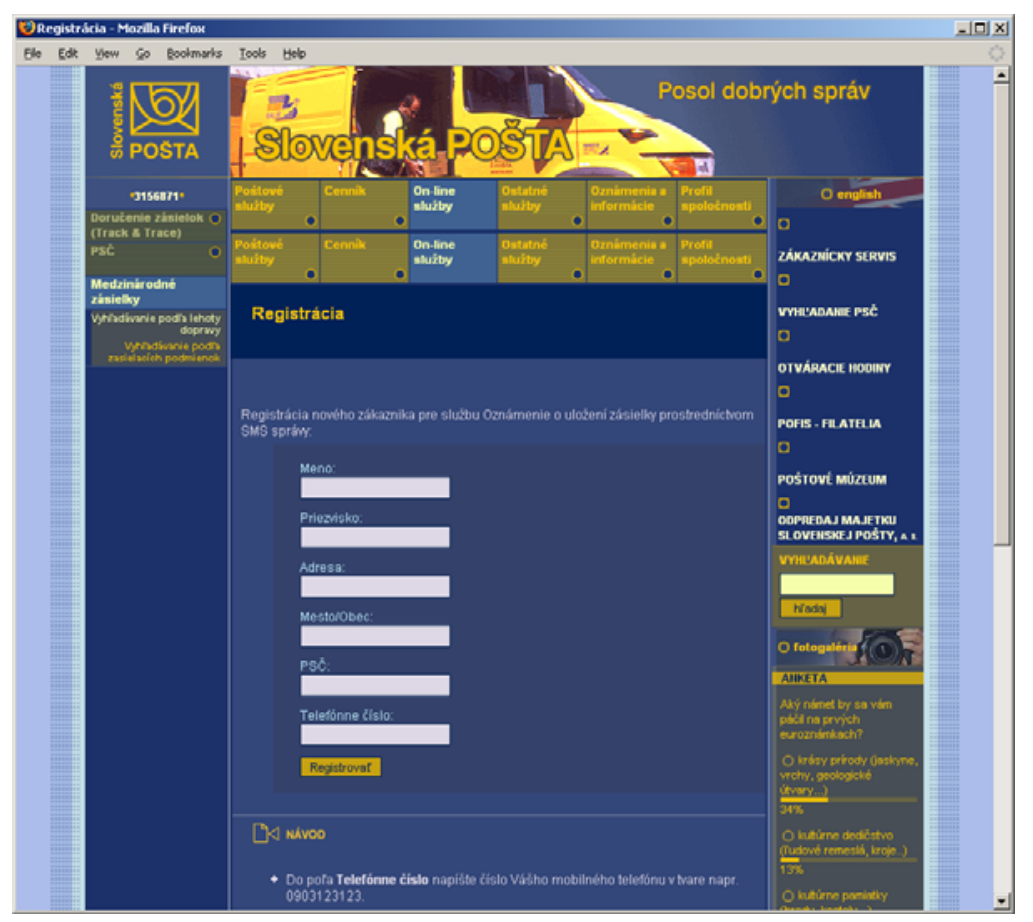

Obr. 1 Registrácia zákazníka prostredníctvom WWW portálu Slovenskej pošty

\subsection{Pracovník pošty}

Proces oznámenie o uložení zásielky prostredníctvom SMS správy je rozšírením pôvodného systému. Pracovník pošty sa pokúsi zásielku doručit'. Ak je adresát nedostupný je potrebné najprv zistit', či je adresát zaregistrovaný, teda rozhodol sa využívat' SMS oznámenie. Ak adresát nie je registrovaný pre službu postupuje sa pôvodným spôsobom vypísaním tlačiva oznámenie o uložení zásielky a vhodením do poštovej schránky adresáta.

Ak je adresát registrovaný, pracovník zaeviduje uloženú zásielku prostredníctvom klientskej aplikácie do systému. Systém spracuje požiadavky a rozpošle SMS správy. Niektoré zásielky sa napr. balíky sa nedoručujú, ale adresát si ich vyzdvihne na pošte. $\mathrm{V}$ tomto prípade sa nezistuje, či je adresát dostupný alebo nie. V tomto spôsobe doručovania sa adresátovi pošle SMS správa s oznámením o uložení zásielky /balíka/ na pošte. Zákazník takto dostane informácie skôr ako by ich dostal doterajším spôsobom - doručením papierového oznámenia do poštovej schránky. 


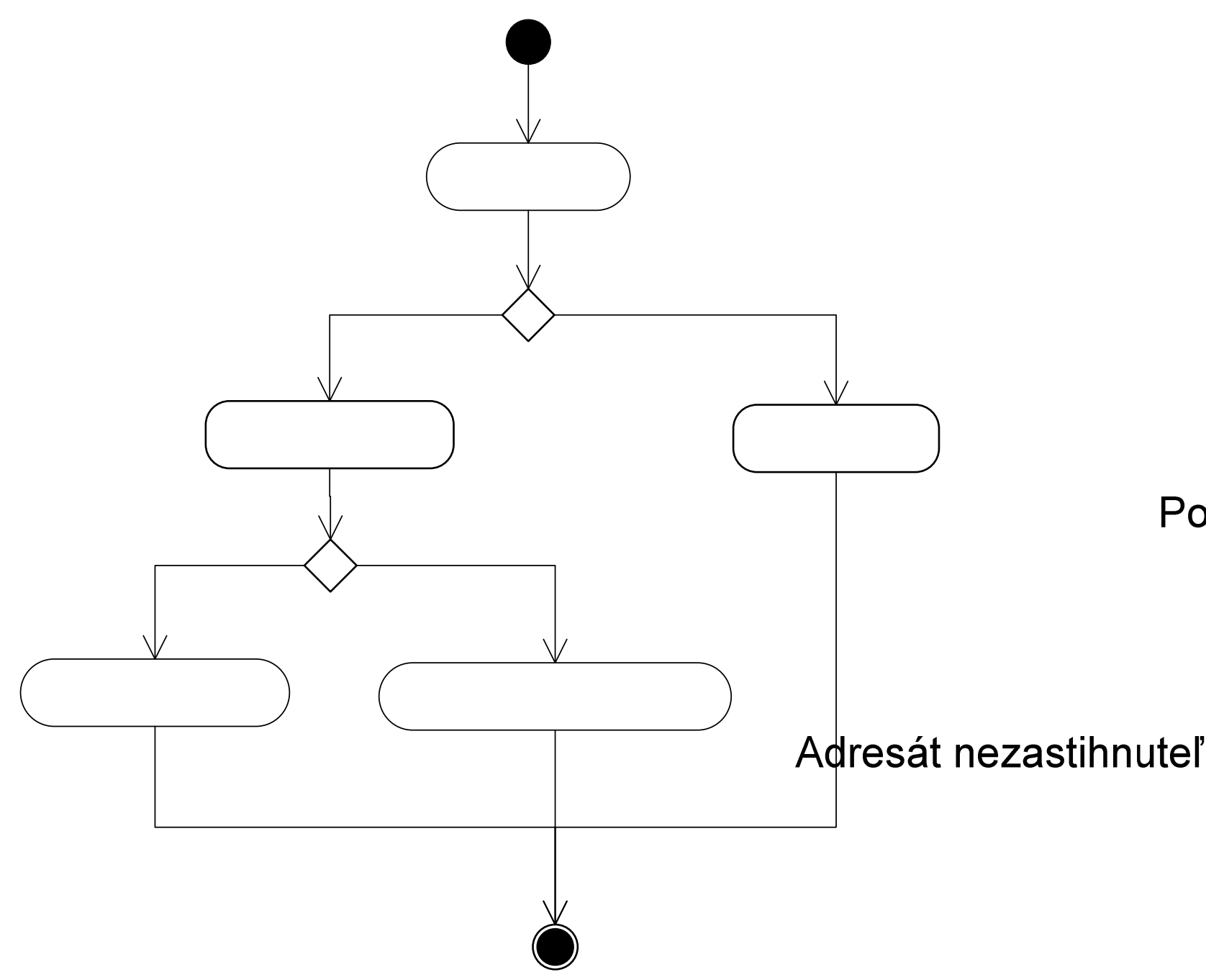

Obr. 2 Proces doručovania zásielok

Zistovanie registrovaných zákazníkov je možné realizovat Je adrostredresát requom apistrocie $\mathrm{v}$ mobilnom telefóne. Týmto je zaručené, že pracovník pošty vie priamo $\mathrm{v}$ teréne $\mathrm{v}$ prípade nezastihnutia adresáta zistit', či je zákazník registrovaný.

Je registrovaný

Nie je 

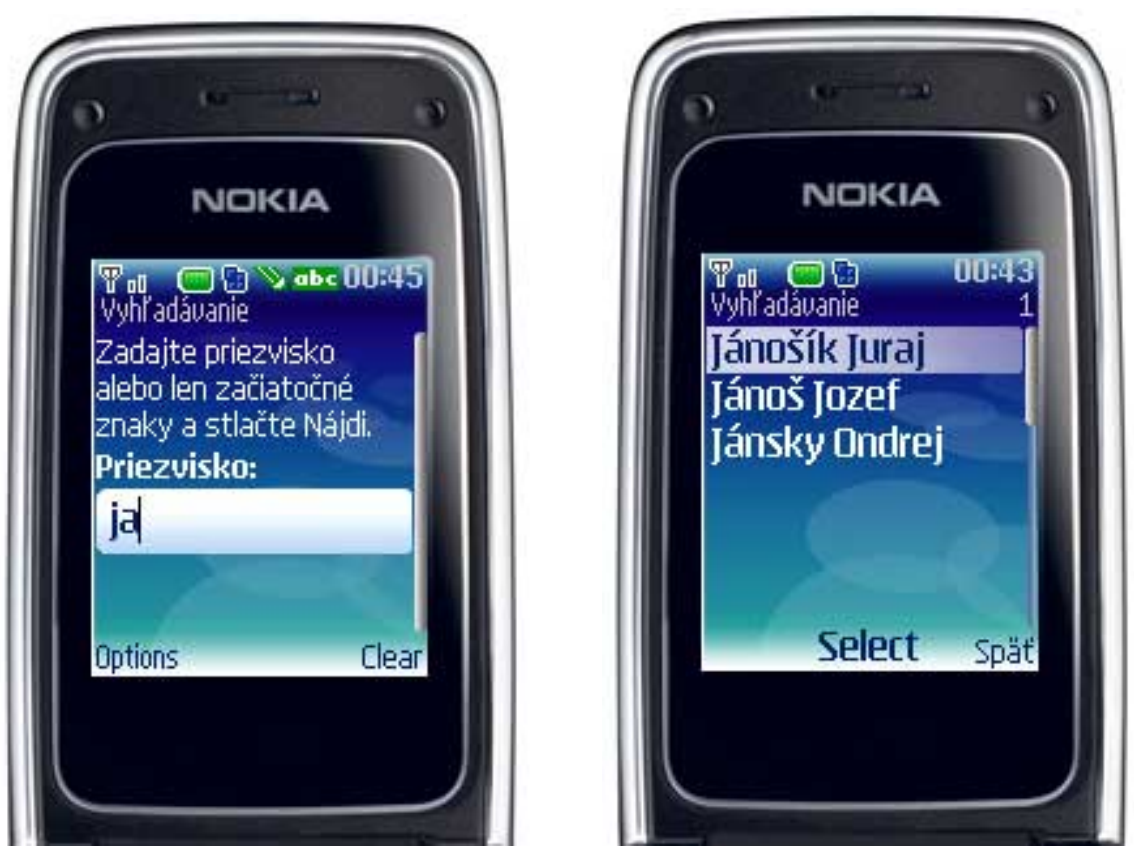

Obr. 3 Mobilná aplikácia - vyhl’adávanie registrovaných zákazníkov

\section{Architektúra systému}

Táto čast' popisuje architektúru systému, rozčlenenie na moduly, externé rozhrania. Celý systém oznámenia o uložení zásielky prostredníctvom SMS správy je založený na automatizovanom softwarovom riešení. Softwarové riešenie je postavené na báze klient sever. Systém môžeme rozdelit' do nasledujúcich modulov:

- Serverová aplikácia - jadro celého systému

- Klientska aplikácia na pobočkách pošty

- Mobilná aplikácia pre pracovníkov pošty na vyhl'adávanie registrovaných zákazníkov 


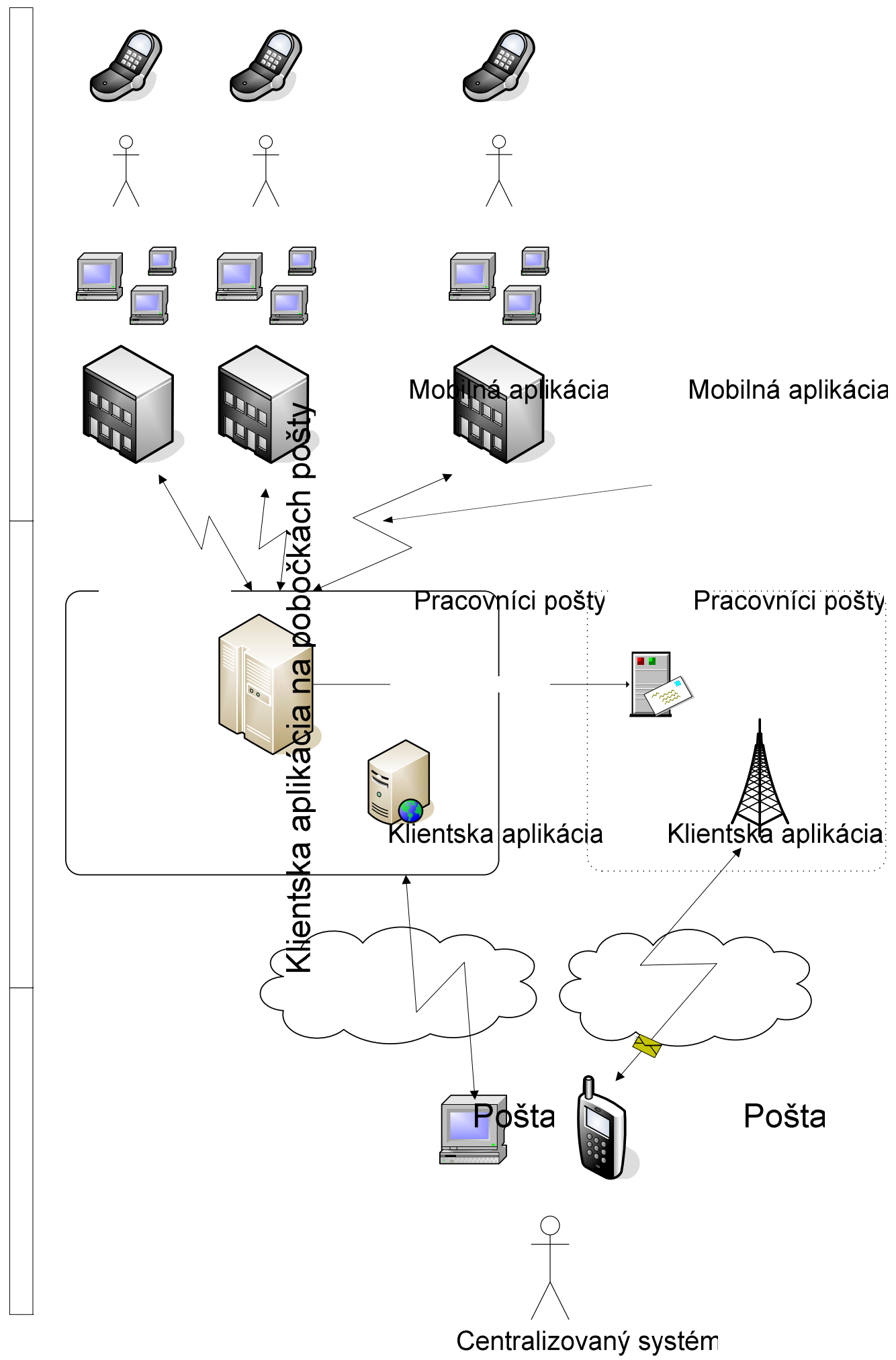

Obr. 4 Architektúra systému

\subsection{Serverová aplikácia}

Serverová aplikácia tvorí jadro celého systému. Zabezpečuje najmä:

- Poskytuje interface pre klieđr]tske aplikácie pobočiek

- Spravovanie registrácii 芴

- Centrálna evidencia uložen⿳亠口冋̆ zásielok 
- Komunikáciu s SMS centrom - posielanie SMS správ, prijímanie registračných správ

- WWW registrácia

Po zaevidovaní novej zásielky systém automaticky zasiela SMS správu zákazníkovi na číslo uvedené v registrácii. Požiadavka na zaslanie SMS správy je odoslaná do SMS centra mobilného operátora.

\subsection{Klientska aplikácia}

Klientska aplikácia je určená pre pracovníkov na pobočkách pošty. Poskytuje najmä:

- Registráciu nových zákazníkov

- Evidencia uložených zásielok

- Vyhl'adávanie registrovaných zákazníkov

- Synchronizáciu dát pre mobilnú aplikáciu

Klientska aplikácia komunikuje so serverovou aplikáciu prostredníctvom počítačovej siete Intranet/Internet.

\section{Rozšírenia systému}

Navrhovaný systém uchováva údaje o uložených zásielkach. Tieto informácie sú dôležité aj pri sledovaní zásielok. Systém je možné d’alej rozšírit' o d'alšie služby ako napr.:

- notifikácia pre odosielatel'a - zásielka bola doručená na poštu, informácia o dobe uloženia zásielky, informácia o doručení zásielky adresátovi.

- poskytnutie informácií o zásielke na vyžiadanie (typ zásielky, odosielatel', dátum odoslania, miesto odoslania).

- notifikácia pre adresáta - adresát môže byt' informovaný už pri doručení zásielky na poštu, pracovník pošty má potom vyššiu šancu zastihnút' adresáta, ktorý už dopredu vie, že mu bude zásielka doručená

\section{Záver}

Návrh popisovaného systému by odstránil mnohé nejasnosti a nezrovnalosti v procese doručovania zásielok a ich notifikácia pri jej doručení zvýšit' spol'ahlivost' služby. Takýto systém by zvýšil kvalitu poskytovaných služieb a zjednodušil procesy následného spracovania, čo by v konečnom rade mohlo odzrkadlit' na spokojnosti koncového zákazníka.

\section{Literatúra}

[1] http://www.itnews.sk/buxus dev/generate page.php?page id=49956

[2] http://www.mobilmania.sk

[3] http://www.mobilmania.sk/Operatori/AR.asp?ARI=7331

[4] http://www.slposta.sk

[5] http://www.zss.sk/dokumenty/vyjadrenie.htm

\section{Grantová podpora}

- MVTS Bil/Nem/SR/ŽU/06 - Pravidlá držiavania sút’aže na trhu elektronických komunikácií

- VEGA 1/4573/07 - Možnosti, ohraničenia a vývojové tendencie koncepcie univerzálnej služby $\mathrm{v}$ pošte a telekomunikáciách $\mathrm{v}$ procese globalizácie 